Dr George R. Wilkes

The University of Edinburgh

grw1000@gmail.com

https://doi.org/10.18485/rit.2021.19.35.11
UDK: 26-67:27

2-673.5

Originalni naučni rad

Predat: 26.03.2021

\title{
INTERRELIGIOUS DIALOGUE AND FEELINGS OF SHAME AND PRIDE ABOUT STATE POWER: A JEWISH CONTRIBUTION
}

\begin{abstract}
Summary:
This essay reflects on the place of shame and pride in interreligious dialogue, focusing on the decades of progress in Christian-Jewish dialogue after the Holocaust and the establishment of the State of Israel. This dialogue has demonstrated what many attempts at dialogue do: dialogues develop in historical contexts marked by the use of power, and partners in dialogue seek a kind of recognition that requires an equality that historic power relationships have obstructed. Feelings of shame and pride have a place at the table even where partners seek to construct an interreligious dialogue that is non-political and separated from historic tensions. Jewish partners to Christian-Jewish dialogue have brought resources from their own religious tradition to engage with these feelings, often centred on their own agency and responsibility, instead of matching the discourses about historic Christian power that have been central in the recent history of Christian-Jewish dialogue. The essay indicates how engaging with responses that reflect such subjective feelings can strengthen efforts to build peace through interreligious solidarity, even where dialogues are intended to focus participants on advancing an agenda identified instead with agreements based on principles and reason.
\end{abstract}

Key words: shame, pride, Christian-Jewish dialogue, peace building

\section{Introduction}

To be comfortable talking about the pride and the shame we feel about historic events that turn people against each other is one of the most challenging tasks for anyone who seeks to build bridges across communities. I have been involved in interreligious dialogue for three decades, and the most powerful educational experiences I have gained from this have been when hearing a speaker share their feelings about events they have lived through, events whose traumatic shadow continues to divide people decades later. In what follows, the history I am reflecting on relates to the dramatic changes in Christian-Jewish relations in 
the twentieth century, and on the creation of an international dialogue movement that has changed the ways in which Jews and Christians talk to each other. We share solidarity in the face of colossal failures in the past, and our feelings about those failures are as important to our attempts to build relations as our analysis of what we share in common, or how we should reason about our differences. I will outline here how the impact of feelings on interreligious encounters is a marker of the ways in which religious and social divisions shape our sense of ourselves. In building religious understanding, a committed dialogue partner will meet their own sense of responsibility in such events, and will sense, too, the limits of their own agency - in short, interreligious dialogue is an exercise in moral psychology; it is not simply an attempt to promote understanding about doctrine, faith, and philosophy. The late Father Sergei Hackel - a beloved Russian Orthodox intellectual who lived in Britain - was a master of this engaged moral psychology, and what follows is intended as a tribute to his memory.

This essay reflects on the place of shame and pride in interreligious dialogue, focusing on the decades of progress in Christian-Jewish dialogue after the Holocaust and the establishment of the State of Israel. In this dialogue, Jews and Judaism may be seen as the minor partner, numerically, or in terms of institutional power. Nevertheless, the consciousness that Christians have of the harms done to Jews in the name of Christianity over the millenia also theoretically may make the position of Jews in this dialogue central, and strong, and Jews living as numerically small minorities may find many practical reasons for committing themselves to dialogue and mutual understanding. A range of emotional dynamics have therefore had a constant impact on Christian-Jewish dialogue, and having examined this, the essay then examines further the ways in which reasoning about morality across cultural divides is affected by our ideas of moral psychology, our understanding of what shame and pride are in particular. As Christians and Jews, reasoning about shame and pride is unavoidably different after the onset of modernity, and particularly where secular thought has influenced our ways of thinking about states, nations and their actions. Naturally we look back into our traditions for an anchor that is strong enough to stand in the face of political fashions and fortunes. I will present some pre-modern Jewish ideas about shame and pride in order to give some context for thinking about the ways in which Jewish religious figures have thought about the Holocaust and the State of Israel. My first interest lies in highlighting how complicated these feelings can make our attempts to build bridges. But if we can tackle our complicated feelings in a non-judgemental dialogue, these complications can also strengthen our relation- 
ships. As much as we may see that emotions such as shame and pride increase the distance across religious, political and cultural barriers, they can also provide a reminder that we cannot be reduced - by shame or by pride - to the secular languages of statism, or of apolitical neutrality, without losing a part of our rich traditions of moral psychology. It is for this reason that I am concerned to indicate that shame and pride have a place at the discussion table when religious people seek dialogue.

\section{Shame and pride in pre-modern Jewish texts}

Shame and pride featured as everyday challenges in an ancient rabbinic moral psychology that centred on the uncontrollable nature of desire. The struggle with desire - which bears some comparison with the portrait of the struggle with desire in the work of St Augustine of Hippo - is complex because human psychologies are complex, and affected by their environment. This strand of thinking has been pursued throughout the development of medieval and modern Jewish thought.

Rabbinic ethics and moral psychology developed through the period in which the primary compendia of rabbinic texts were compiled: the Mishnah (c. $130 \mathrm{CE}$ ) and then additional commentaries in the Jerusalem and Babylonian Talmuds (c. 350-550 CE), alongside additional midrashic commentaries which made great play of the psychological dramas featured in the Bible. The texts represent themselves as a faithful, if critical, reflection of the Pharisaic tradition, which at the time of Jesus - sought to transform prophetic and priestly forms of Judaism into a wisdom tradition that could be applied by pious and educated communities without the special divine interventions that prophets and priests had once evoked. The scholarly tradition of the 'Sages' described in these works was also identified increasingly over this period with the role of the teacher, Rabbi, and so subsequent generations of Jews have identified their scholastic tradition - rooted in the Bible and in the thought of the Pharisees - as 'rabbinic Judaism'.

The primary concept used in these rabbinic texts in describing the struggle with desire is the notion that human choices are regulated by two drives, one which may be translated as the drive to do good (the yetser ha-tov) and the other as a drive to do evil (the yetser ha-ra). From the earliest times the notion of a straightforward distinction between these orientations - the idea that they are defined by being oriented towards an objective good and evil - has been problemtised. The rabbinic texts represent both drives as necessary - and indicate that 
much good would not be possible without the yetser ha-ra, another way of suggesting that selfish motives may lead to the public benefit. The 'good inclination' was as important for moral psychology as the 'evil inclination' - early rabbinic Judaism was far from the religion of prohibition and guilt presented by Freud in Moses and Monotheism (1939). Rabbinic texts maintained that the intention to do good was an important part of a person's good deeds, but they did not represent this as a straightforward reflection of rational powers or inherent holiness.

These two internal forces may be represented as psychological drives, or alternatively as inclinations: the 'drive to do evil' may be a kind of Freudian ego; an 'inclination' may seem more fitting where the rabbinic psychology is being related to an Aristotelian schema, according to which good deeds reflect reason and a sense of moderation. At the same time as an individual may be described as struggling with their yetser ha-ra, the agency of an individual to regulate their personal yetser could be affected by their spiritual environment, which is also subject to a struggle between good and evil forces. The impact of internal and external factors on an individual's psychological disposition is a readily recognisable feature of rabbinic psychology. Shame and pride arise in this complex context, in which an individual struggles with what they know internally to be right or wrong, and how they seek to enact their moral standing in their community. Paul, like other Pharisees, drew deliberately on metaphors attributed to the prophets of the Hebrew Bible which distinguished internal and external indicators of moral behaviour: the heart and the lips, for instance (Sanders 2016, esp. 311-26). Shame and pride were emotions that reflected both an internal moral force and an external relationship. An individual could not expect to perfect their moral capacity without practice, and without engagement with the community. Since the propensity to ethical wrongdoing was absolutely normal for members of human communities, it should be counted upon, and, although it should be checked, wrongdoing was not in itself grounds for social exclusion. Responsible actors would need to be careful to respect the challenges that individuals would have in developing their moral stature, making allowances for weaknesses and sensitivity. The rabbis adjured their followers to be extremely careful not to humiliate or shame another person (Mishnah, Pirkei Avot 3:1), and to be careful to avoid harmful speech. They argued for the absolute importance of perfecting one's character traits in order to ensure righteous behaviour - to act in complete humility for instance - and yet they also presented such perfection as nearly impossible (Jacobs 1995).

Rabbinic discourses about shame and pride could therefore be capable of reflecting contradictions between the internal and external processes at stake in 
moral psychology, recognising that there were intangible relationships between the two. For this reason, a simple dichotomy, for instance, between good and bad, or between internal guilt and external shame (Ehud Luz 2003), does not do justice to the textual basis for subsequent Jewish thought. When the great twelfth century rationalist Moses Maimonides - still today an authoritative figure for Jewish thinkers of most communities and religious movements - wrote about character formation, he borrowed most of the Aristotelian language about moral excellences or virtues being found in the middle between extremes of behaviour. However, with respect to anger and pride, he noted the rabbinic tradition was to completely reject these as harmful, not to seek to balance them with a countervailing virtue (Maimonides, Commentary on the Mishnah, Eight Chapters). Jewish ethical teaching - mussar - has also been greatly influenced by Sufi teaching, in which the internal, spiritual aspect of character development is stressed immensely. At the same time, mussar teaching has (in all its diversity, in medieval Spain, in pietistic texts modelled on the Kabbalah, and in modern Chassidic and Lithuanian verions) stressed the degree to which internal and external conflicts are related; that sins, however shameful, are as normal as other mistakes; that moral accomplishments are as mercurial as any other reason for pride; and that the religious Jew must seek to exert their moral influence on situations even in the knowledge that the fault of others, even the fault of previous generations, makes good outcomes difficult to achieve. The religious Jew must not only do the right thing, he or she must be careful to show their concern for doing the right thing - upholding God's Law and sanctifying the name of God (kiddush HaShem) entailed taking care not to seem to be accepting a lower standard of behaviour, let alone immoral behaviour. To appear to accept wrongdoing was to place an obstacle in the way of the ordinary person's ability to improve their moral comportment and compliance with the law - even if was only an appearance created by not declaring what was right conduct. Jewish communities may have often represented their moral qualities as a source of especial pride, by contrast with the crimes committed in the name of other religions by much larger and more powerful Christian and Muslim peoples. Within religious Jewish communities, the knowledge that this is an accident, that given the power to do ill, Jews would be just as capable as Christians and Muslims, is identified with a well-known quotation from the twelfth-century Spanish writer Judah HaLevi, whose writing on shame and pride is also known for its sophisticated representation of the desire for return to the land of Israel as all-consuming and yet almost-impossible to achieve. Judah HaLevi imagines an interreligious dialogue staged by the king of the Khazars, who asserts to 
his Jewish interlocutor that if Jews were ruling they would be as prone to misrule as anyone else. 'You have touched my spot of shame,' replies the rabbi (which Hirschfeld 1905, I: 115, translates as 'weak spot').

\section{Dialogue, Reason and Emotion}

Interreligious dialogues commonly present a very modern face to dealing with difference, especially in contrast to the apparently medieval model of an interreligious encounter as an attempt to convert an opponent and to vanquish their arguments for an inferior faith. As an organised phenomenon, they developed at the turn of the twentieth-century through a combination of scientific investigation of what religions share in common, and an optimism about the ability of national and religious culture to provide a resource for building world peace. It was reason and rational principles rather than emotion which has provided the focus for the development of organised dialogue movements, though not divorced from a lived and felt context. Marcus Braybrooke, a dedicated champion of interreligious dialogue, has shown in his historical overview of the development of the World Congress of Faiths (Braybrooke 1996) that the institutional development of interreligious dialogues owed a great deal to the experience of Protestant missionaries in the early twentieth century, who discovered how important for the integrity and success of their mission it was to recognise the values that are shared by non-Christian faiths. The insight that shared values constitute a basis for new forms of mutual recognition has been seen by advocates of interreligious dialogue as a practical resource for social progress, and for international peace. This, according to theorists and practitioners of this interreligious dialogue, is not only a modern phenomenon, it also rests on the revolutionary ideas shared by the biblical prophets with other new religious and philosophical developments in the Axial Age (from the $8^{\text {th }}$ to the $3^{\text {rd }}$ century BCE), in China, in India and the Middle East. This approach to building an awareness of shared public values through interreligious dialogue was extended by the new focus on 'world religions' - each sharing core values - in Christian theology faculties from the 1970s (see, for a reflection which takes this perspective, Hick and Swidler 1987), and more recently, at the turn of the twenty-first century, it has been followed by a series of public programmes attempting to spread the multireligious Axial Age teachings of compassion, peace and social ethics (Küng and Kuschel 1993, Armstrong 2006, 2011). In recent decades, the 'world religions' paradigm has been widely taught, but also widely criticised, as representing less how non-Christians see themselves 
and more how a Kantian would want them to understand their relationship to the world (Cotter and Robertson 2016).

These doctrines of interfaith dialogue were intended to rectify the sense that there was a loss of humanity in the secular space, and they did so through the representation of religion as a universally available resource for reasonable discourse, much as secular thought had attempted to be, which societies grasp more firmly than the ahistorical postulates of Kantian philosophy. For religions to be humanising, they have to be a part of the discourse of the humans they are designed for, and proponents of interreligious dialogue have argued that it is precisely because they bring both the universal and the particular together that they are capable of producing an engaged encounter which is centred on real humans, and not only humanity in the abstract. For this to be made real, Küng has argued, dialogue partners representing the different world religions must show that they can recognise the importance of the other religions. The intellectual work needed for that mutual recognition is an urgent priority. As Küng put it: "No peace among the nations without peace among the religions. No peace among the religions without dialogue between the religions. No dialogue between the religions without investigation of the foundation of the religions." (Küng 1995)

Alongside this model of interfaith dialogue as a process of reasoning about human value lies a second model focused on an individual's emotions instead of aiming at pure reason, and this is equally foundational for the modern movement to bring believers of different faiths together. In this approach, the emotions generated by a dialogue between two people who seek to fully understand each other are an important part of the process itself - they establish the meaning of the relationship, and they are necessary for a real process of mutual recognition in which individuals perceive each other as independent subjects in their own right, not as mere objects to fit into a pre-existing schema. An optimistic version of the promise of this subjective approach to dialogue might be found in Martin Buber's I and Thou (Buber 1923/1937), though many advocates of a personalist interfaith dialogue refer instead to the work of Søren Kierkegaard as reflective of a fuller set of religious reasons for treating the subjective, emotional self as being of central importance - and this commonly reinforces an argument for respecting the independence of religious traditions in an encounter between people of different faiths.

The different conceptual frameworks for interreligious dialogue might be viewed not as opposites but as tendencies at different ends of a spectrum. Instead of seeing one as more liberal and embracing of encounters with a religious 'other', and the other as more opposed to liberal conceptions based on common val- 
ues or fellow-feeling because they seem 'untrue' or 'unrealistic', it may be seen that advocates of interreligious dialogue can combine elements of both approaches to respond to their perception of the situation we encounter in modern, or postmodern, times. When Jewish intellectuals place themselves in dialogue with Christianity, as Eugene Fisher observed (Fisher 2010), Kierkegaard functions as every Jewish thinker's favourite Christian, and this can be said for many liberal Jews as well as more conservative thinkers. One reason that Kierkegaard appeals is that his work expresses the difficulties of speaking across boundaries of experience and across communities of professed differences of faith.

This may not reflect the experience of ordinary Jews and Christians who live in proximity to each other and who can share their lived experience with each other in the same language. The philosophy of dialogue is instead intended as a response to the expectation of making intellectual progress through dialogue, and this expectation remains widespread far beyond the most liberal proponents of interreligious engagement. This is shared by the philosophically minded theorists of dialogue whether they argue for a more personalist form of dialogue or a conversation about common values and principles. Behind this expectation lies the understanding advanced by Kant and Hegel that the self is formed through a process of negation of other selves, other subjects and objects. To be able to take control of this process, early twentieth century advocates of interreligious dialogue particularly of Christian-Jewish dialogue - argued that faiths should be seen not as isolated from each other, but as affirming each other by their very determination of the differences between what they class as 'self' and 'other'. Identifying the process of dialogue - or 'the negation of negations', in the language of Hegel - with Christian-Jewish encounter, Franz Rosenzweig (Rosenzweig 1921) influenced generations of thinkers to see interreligious dialogue not as either 'rational' or 'subjective' and 'emotional', but as both. It is both because it involves reasoning about boundaries between the self and the other which are not easily understood, digested, and labelled. It is both because it requires a participant to engage with their full sense of self, with the history they are attached to and with their hopes for the future.

Practical attempts at interreligious peacebuilding today may be a million miles away from the conceptual struggle over the self and the other that motivated German thinkers a century ago. Nevertheless, they encounter similar issues of self and other to the extent that the terms set for the dialogue still involve formulations used by the dominant approaches to knowledge at that time: particularly those that responded to the realities of life as an adherent of a religious 
faith in the modern state, and those that responded to the beliefs about the separation of the individual which followed from the claims made about the self by Descartes. Where we revert to religious traditions which pre-existed Descartes, be they Christian, Jewish, Muslim, Buddhist, or other, we still encounter modern assumptions about the self and the state. It is a challenge to reformulate our conversation about the differences between us without the mix of assumptions about self/other, political/personal and public/private which have characterised formal public expectations about religions, and about the bases for respect and recognition across religious boundaries. This is also true of the emotional realities which we bring to dialogue with each other about other aspects of our personal and political lives, features of our individual and collective lives about which we are ashamed, proud, or have other feelings. What will become clear in describing some more or less well-known Christian-Jewish encounters after the Holocaust is that there are ways in which the power dynamics implied in dialogue encounters can produce emotional effects which are familiar from many other relationships in very different contexts. The attempt to create understanding or to build peace has an emotional dimension which does not disappear when dialogue is attempted, and which is not easily reasoned away.

\section{Christian-Jewish Dialogue in the Wake of the Holocaust}

There is a problem that has recurred in the high-level dialogue between Christian and Jewish institutions: Christian leaders have sometimes expressed that there is not a free, equal dialogue if they have to make concessions about collective responsibility, guilt or shame. The Christian-Jewish dialogue has been talked about as if it is a response to Jewish pressure, and that Jews too should be making concessions in order to restore a sense of equality. The position of the State of Israel in this dialogue raises sensitivities in both Christian and Jewish communities. Pressure is perceived, not because, or not just because, it is exercised by the other party, but because participants in the dialogue respond to the situation they are in with their own sense of what is demanded of them as a collectivity - their own sense of shame and of self-worth as it applies to the Christian party to a dialogue, for instance. In order to advance dialogue and understanding, it is worth also appreciating the feelings of shame and pride that Jewish people carry with them in the wake of the Holocaust, even while focusing attention on rational problems and principles that should guide moves towards justice and reconciliation. 
Early steps in the organised dialogue between Jewish and Christian intellectuals and representative bodies did not focus on antisemitism, but on the establishment of common public values. Christian-Jewish encounter in the USA was focused on the creation of brotherhood between Catholics, Protestants and Jews, and when in Britain the Council of Christians and Jews was established in 1942 it deliberately avoided reference to antisemitism. In 1947, Christian and Jewish intellectuals gathered at Seelisberg in Switzerland to set out the basis for a joint response to their 'alarm' at the danger of a new wave of antisemitism, and formulated ten principles (Seelisberg Principles 1947) which countered antisemitism as historically un-Christian and argued for a Christian reappraisal of the close historic relationship between Christianity and Judaism. The signatories established the International Council of Christians and Jews, and they played a prominent role in the conversations which led Pope John XXIII to announce the Second Vatican Council, at which the priorities announced at Seeligsberg were presented in concise theological language as Nostra Aetate (1965).

It was widely accepted that the Holocaust was an important motivation for the clarity with which the Second Vatican Council 'deplored' antisemitism and reaffirmed the close relationship of the Church and the Jewish people. Nevertheless, it was not easy for the Church leaders gathered in Rome to acknowledge that Christians had a responsibility for the hatred, discrimination and murder that Jews had faced in their countries, let alone that the Church as a theological body should be seen to have had a responsibility of this nature. Church leaders welcomed private conversations with rabbis who shared their deep theological and spiritual understanding, but when those same Jewish dialogue partners sought recognition that missionary activity targeted at the Jewish people was a spiritual form of antisemitism, this prompted private outrage. After the Council closed, it took until 1985 until the Catholic Church was ready to publish a careful acknowledgement that it was the responsibility of members of the Church to reflect on the involvement of Christians in the Holocaust: as Pope John Paul II underlined, that Nostra Aetate required a theological reflection on 'the extermination of many millions of Jews during World War II' (John Paul II, 1985). This was followed by years of dialogue between Catholic and Jewish interlocutors, in view of the recognition that the Shoah was such a huge moral calamity that it demanded more deliberate engagement. In 1998, John Paul II introduced a document, We Remember, which addressed the Holocaust as it was experienced by Jews, as the Shoah (or 'catastrophe'), as a subject which required remembrance, repentance, and a determination to face the future together with the Jewish community (Vat- 
ican 1998). This was a moment of extreme sensitivity, and John Paul II did not charge the Church with responsibility for antisemitism and mass murder, but regretted the sins of 'the sons and daughters of the Church', Christians who lived in a Europe formed through its Christian civilisation (Vatican 1998). The formal dialogue raised much more than high-minded principles and mutual education: We Remember was both criticised and valued by a wide range of Jewish thinkers and representative bodies, yet the most senior Church and Jewish dialogue specialists found that they continued to have to address their mutual hurts in meetings and statements for the next decade.

The formal dialogue between the Catholic and Protestant Churches and Jewish dialogue specialists from organisations representing the Jewish communities of the West was sensitive for at least two reasons. First, the participants in that dialogue felt the invisible power relationships at stake in different ways. The Jewish figures involved saw the Catholic Church as the most influential global institution which had become an ally against antisemitism, and they engaged with it with gratitude and anxiety. Cardinal Cassidy, Cardinal Keeler and other figures involved in drafting We Remember saw their role as an important counter to the attack on the integrity of the Church that had been led by Communists and their Western sympathisers, particularly in response to attacks on the record of the wartime Pope Pius XII. We Remember was a riposte to secularist anti-clericalism, and Church figures responded with sensitivity when Jewish interlocutors seemed to accept unfair critical perspectives on the role of the Catholic Church during the Holocaust. The power dynamic they saw was not the Church's global strength, but its vulnerability in the face of continuing public antagonism at the turn of the millenium. Second, this element in the post-1945 dialogue clearly raised issues at which Christians might naturally feel shame, as well as criticisms for inaction which many Catholic leaders did not accept feelings either of retrospective responsibility or of shame. Antisemitism and the Holocaust were high on the agenda of the official Catholic-Jewish dialogue liaison committee because issues associated with moral responsibility and shame within the Church had not been clearly addressed in statements made in previous decades - and because both Jewish and Catholic participants had faith that they could address this effectively. Through the years between the publication of the Notes of 1985 and We Remember in 1998, while the Church sought to advance its collective understanding of the significance of the Shoah for Catholic-Jewish relations, sensitivities stoked heated and repeated conflicts over the remembrance of the Shoah in Poland, and these conflicts made 
for a 'difficult' period of dialogue at an international level, as Cardinal Cassidy recalled (Cassidy 1998).

After the Second Vatican Council, the revolution in Western Church teaching about Jews and Judaism also addressed the creation of the State of Israel, a point on which under Communism the Orthodox Churches were not free to fully express themselves. From the public statements of the Catholic Church and of a number of Protestant churches, the importance of the State of Israel to Jewish people could be seen to reflect the affirmation that Christians had to reverse an age-old practice of viewing Jews and Judaism through an antagonistic lens, rejecting what they believed it to be rather than accepting what Jews themselves described as important to them. Before the Holocaust, the notion of a Jewish state was even seen as theologically challenging. The fall of the Temple in Jerusalem and of an independent Jewish state at the hands of the Romans was represented as part of the conditions in which God's favour could be seen to have passed to the Christians, and the covenant with the Jews had been superseded. To revive a Jewish state contradicted this. The Churches after the Holocaust rejected this 'supercessionism', rejected (as Nostra Aetate put it) a 'triumphalist' approach to the relative strength of the Church vis-à-vis the Jewish people, and therefore rejected the 'teaching of contempt' according to which Jews could not define their vision of their public role in the world independently.

The recognition of the State of Israel was of course a much more complex challenge than the straightforward reversal of the teaching of contempt. Still at the time of the Second Vatican Council (1962-65), many Christians did not accept the State of Israel had the right to exist - many Jews also rejected the project of a Jewish state. Pope Paul VI may be seen to have made a gesture at recognising the significance of the State of Israel to the Jewish people in his acts during his visit to Palestine in 1965 , but at this stage the international situation still placed huge political obstacles in the way of a reconciliation between the Church and the State of Israel. The 1967 war changed the balance of opinion within Jewish communities worldwide, as Jews feared and perceived that the international community was allowing a second Holocaust to take place. In November 1975, the General Assembly of the United Nations passed the 'Zionism is racism' resolution, and the Churches of the West were confronted with the weightiest coalition to date that sought actively to deny the right of Jews to have a state of their own. A number of Protestant churches issued statements indicating that they accepted or supported the right of the State of Israel to exist, and opposed the campaign led by the Communist and Arab states against Israel. The Catholic Church made clear 
in its Notes on Nostra Aetate of 1985 that the State of Israel was to be seen not as religious but on the basis of the principles of international law (Vatican 1985). In 1987, Pope John Paul II told Jewish dialogue partners that he could understand that the Jewish people might see the State of Israel as the fulfilment of ancient prophecy (Keeler 2003). In 1993, as the peace process initiated in Oslo began to result in major political shifts, the Vatican formally recognised the State of Israel. Pope John Paul II made clear with a penitent visit to the Western Wall during his visit to Israel in 2000 that he recognised the religious importance of Jerusalem to Jews as part of his mission of reconciliation. None of this shift can be understood without reference to the power relationships which governed international politics at the time. Against the movement in favour of recognising the State of Israel, there remained the continuing political clashes over the rights of Palestinians, and over their treatment in the occupied territories. This complex reality weighed equally on many Jewish participants in Christian-Jewish dialogue changing relationships and the changing political situation presented both parties to the dialogue with defensive feelings of shame and failure to exercise responsibility effectively.

\section{Jewish Responses: Shame and Pride}

An attempt at an objective account of the power relationships that help to shape organised Christian-Jewish dialogue - the dialogue between representatives of the Churches and major Jewish organisations - might be helpful in constructing a perspective in which the State of Israel's defence is an interest of the Church's Jewish interlocutors, and therefore its place in the dialogue could be expected to largely reflect the commitment of Jewish dialogue partners - and to the same table the Church would bring other interests, such as a recognition of the progress made in combatting antisemitism, or recognition of the claim of Jesus and of Christian teaching to have a special relevance for Jews today. This kind of objectivism produces a caricature of interpersonal and intercommunal relationships. The Holocaust could enter the dialogue as a shame on the ledger of the Church, for instance, about which Jewish interlocutors would be expected to make restrained judgements in exchange for their own interest in solidarity against antisemitism and anti-Zionism. No doubt there are individuals who weigh such interests in approaching dialogue, approaching them as a trade-off or a zero-sum game, reducing the quality of relationships to the attainment of particular objectives. 
This kind of judgement may fare more or less well with dialogue that relates to historic events involving strong emotions, such as shame and pride, depending on the ways in which dialogue partners relate those emotions to their own personal sense of responsibility and agency. From a distance, it may seem that attitudes to antisemitism, to the Holocaust, and to the State of Israel, may be judged neatly in terms of rational actors exercising clear responsibilities. There may therefore be rational reasons for asserting that Christian and Jewish actors should feel an appropriate or a good kind of shame for failures to take responsibility for some acts, and that they may safely reject unhealthy, bad types of shame where they were and are not responsible. Jewish religious resources do not rest with such straightforward judgements, judgements which do not reflect the traditions of ethical sensibility outlined above.

Some examples here will indicate how this translates into practical contexts in the public sphere and in contemporary dialogues. At the end of the Second World War, one of the most prominent Jewish spokesmen was Nachum Goldmann, who had co-founded the World Jewish Congress in 1936 and who was its President from 1949 until 1977. Goldmann and his colleagues had played an important role in alerting the international community to the first reports of the death camps in Poland in 1942, and devoted himself to attempts to rescue Jewish communities from the Nazi regime. Yet, at the end of the war, Goldmann concluded that the shame of not having been able to save more Jews was the greatest burden he and his generation of Jewish community leaders would carry for the rest of their lives (Goldmann 1978). This consciousness marked his many interactions with the German government after the war, notably on the subject of post-Holocaust reparations, and his voice differed from the many observers who sought to deal with post-war German-Israeli relations through an interest-based negotiation.

While Goldmann conceived the question of responsibility and shame on a separate plane from the public political stage, the British Chief Rabbi Immanuel Jakobovits sought to make a comparable intervention in talking of the shame of the existence of the camps in Gaza. Although Jakobovits maintained throughout his career that he was careful not to criticise the decisions of the political leaders of Israel, nor those of the UK government, he provoked repeated controversy in the 1980s for his support for a peace process that would lead to the establishment of a Palestinian state. He spoke out, he explained in a book, If Only My People (1984), because it was his responsibility as a rabbi. He was speaking as a proud Zionist, who identified with a true Zionism that was religious rather than secular. 
Peace and justice for Palestinians was not, he argued, a purely political issue, but a moral one. What motivated his critique was a religious stance which he equated with the Jewish tradition's prophetic legacy. The demand placed on him was to declare what was right before Heaven and before his people, and this firstly meant speaking out in favour of long term peace. In addition, he argued that the Jewish tradition mandated speaking out in favour of a moral vision because it was a sanctification of God's name, a kiddush HaShem. Near the end of his period in office, he declared the continued existence of the refugee camps in Gaza a 'stain on humanity'. Although he said that Israel was not to blame for the creation of the problem, he nevertheless argued 'We cannot forever dominate a million and a half Arabs. This blinkered view is self-destructive' ('Chief Rabbi Shames Israel', Evening Standard, 23 May 1991). Jakobovits' public definition of a moral voice was not designed simply to avoid shame by currying favour. It was a public perspective shared by a number of prominent religious Zionists at the time, determined to provide public moral guidance that would reflect the heritage of Israel in a voice that conveyed moral integrity.

\section{Conclusions}

It could be that what has been presented here appears to be a particularly religious, even pious, set of Jewish responses to power, to political rights and political wrongs, to causes of public pride and shame. There is another way of constructing the Jewish ethical tradition, mussar, described here, which allows that many Jews are drawn to it even while not being pious, religious adherents or even believers in a traditional sense - the tradition of 'Jewish ethics' is much evoked by nominally secular Israelis in defining what they believe a Zionist polity should be governed by. This ethical tradition finds a model for political justice, or prophetic justice, in Jewish texts that focus on interpersonal relationships - a tradition which could be seen to begin with the Bible. Contrasted with a narrow political 'realism', these texts speak of shame and pride as a feature that marks and that should mark public discussion, as indicators of the human level in the political sphere.

It follows that a dialogue which engages with a community which maintains the importance of a personal quality in the public sphere should be attentive to the complex of emotions and perspectives which make public issues feel real to real people. After the repeated traumas experienced by Jews, Christians and Muslims, Israelis, Palestinians and others, in Europe and in the Middle East, a dialogue that 
draws meaningfully on this ethical tradition would seek to embrace what is personally meaningful, while being very careful with peoples' emotions, their anger, their sense of shame - even if this may delay discussion of fundamental principles, final settlements, and the full demands of justice. The ability to engage in such a dialogue with care and restraint proceeds from the recognition that moral emotions are a feature which depend on the complexities of human psychology. While interreligious peacebuilding through dialogue can helpfully embrace feelings of shame about atrocities, and pride about state power, embracing these feelings in the context of a rich interreligious reflection may not mean addressing these emotions head-on. Richness in our religious traditions, a feature that draws us to them, theoretically opens a space in which shame and pride can be encompassed even where this is seen as too complicated for political reconciliation initiatives. But this can only be achieved step by step, as the successes and challenges of the official Catholic-Jewish dialogue have shown. In a space of real interpersonal encounter, feelings of shame and pride need no longer be reduced to a more simplistic moral psychology which relies on judgement and rational justifications. As the post-Holocaust dialogue has repeatedly demonstrated, translating the interpersonal solidarity created in such dialogues into a wide public understanding involves further challenges, in which the metaphors and models of personal morality meet with political conditions that demand a different kind of personal attention and commitment.

\section{Bibliography}

Karen Armstrong (2006). The Great Transformation: The Beginning of our Religious Traditions, New York: Knopf.

Karen Armstrong (2011). Twelve Steps to a Compassionate Life, London/New York: Penguin/Random House.

Marcus Braybrooke (1996). Wider Vision: A History of the World Congress of Faiths 1936-1996. Oxford: One World.

Martin Buber (1923/English translation 1937). I and Thou. Edinburgh: T. \& T. Clark.

Cardinal Edward Cassidy (1998). 'Reflections on the Holy See's Statement on the Shoah', Catholic Review, Vol. 9, No. 10, 448-453.

https://www.catholicculture.org/culture/library/view.cfm?recnum=658.

Christopher R. Cotter; David G. Robertson, eds (2016). After World Religions: Reconstructing Religious Studies. London and New York: Routledge.

Eugene Fisher (2010). 'Typical Jewish Misunderstandings of Christianity', Shofar

Vol. 28, No. 3, Jesus in the Context of Judaism (Spring 2010), pp. 57-69.

Sigmund Freud (1939). Moses and Monotheism. London: Hogarth Press.

Nachum Goldmann (1978). The Jewish Paradox. London: Grosset \& Dunlap. 
John Hick and Leonard Swidler, eds (1987). The Myth of Christian Uniqueness: Toward a Pluralistic Theology of Religions.

Hartwig Hirschfeld (1905). Judah Hallevi's Kitab Al-Khazari. London: G. Routledge.

Louis Jacobs (1995). The Jewish Religion: A Companion. Oxford: Oxford University Press. Reprinted at https://www.myjewishlearning.com/article/humility-in-judaism/

Chief Rabbi Immanuel Jakobovits (1984). If Only My People: Zionism in My Life. London: Weidenfeld \& Nicholson.

John Paul II (1985). http://www.vatican.va/content/john-paul-ii/en/speeches/1985/october/documents/hf_jp-ii_spe_19851028_chiesa-cattolica-ebraismo.html.

Cardinal Keeler (2003). 'The Catholic Church and the Jewish People', address to the Utrecht conference of the International Council of Christians and Jews. https:// www.bc.edu/content/dam/files/research_sites/cjl/texts/cjrelations/resources/articles/keeler ICCJ 2003.htm

Hans Küng and Karl-Josef Kuschel, eds (1993). Global Ethic: The Declaration of the Parliament of the World's Religions. London: Bloomsbury.

Hans Küng (1995). Christianity: Essence, Future, History. London: SCM Press.

Ehud Luz (2003). Wrestling With an Angel: Power, Morality and Jewish Identity. New Haven CT: Yale University Press.

Nostra Aetate (1965) http://www.vatican.va/archive/hist_councils/ii_vatican_council/documents/vat-ii decl 19651028 nostra-aetate en.html

Seelisberg Principles (1947). https://www.ccjr.us/dialogika-resources/documents-and-statements/ecumenical-christian/seelisberg.

Vatican (1985). https://www.bc.edu/content/dam/files/research_sites/cjl/texts/cjrelations/ resources/documents/catholic/Vatican_Notes.htm.

E.P. Sanders (2016). Comparing Judaism and Christianity: Common Judaism, Paul, and the Inner and Outer in the Study of Religion. Minneapolis: Fortress Press. 


\title{
Dr George R. Wilkes
}

Univerzitet u Edinburgu

grw1000@gmail.com

\section{INTERRELIGIJSKI DIJALOG I OSEĆANJA STIDA I PONOSA O DRŽAVNOJ MOĆI: JEVREJSKI DOPRINOS}

\begin{abstract}
Rezime:
Ovaj esej odražava mesto stida i ponosa u međureligijskom dijalogu, fokusirajući se na decenije napretka u hrišćansko-jevrejskom dijalogu nakon Holokausta i uspostavljanja Države Izrael. Ovaj dijalog pokazao je ono što rade mnogi pokušaji dijaloga: dijalozi se razvijaju u istorijskom kontekstu koji je obeležen upotrebom moći, a partneri u dijalogu traže neku vrstu priznanja koja zahteva jednakost koju su istorijski odnosi moći ometali. Osećaj stida i ponosa ima mesta za stolom čak i tamo gde partneri žele da stvore međureligijski dijalog koji nije politički i odvojen od istorijskih tenzija. Jevrejski partneri u hrišćansko-jevrejskom dijalogu doneli su resurse iz sopstvene verske tradicije da se bave tim osećanjima, često usredsređenim na sopstvenu odgovornost, umesto diskursima istorijske hrišćanske moći koji su bili centralni u novijoj istoriji hrišćansko-jevrejskih dijaloga. Esej ukazuje na to kako angažovanje u odgovorima koji odražavaju takva subjektivna osećanja može ojačati napore za izgradnju mira kroz međureligijsku solidarnost, čak i tamo gde su dijalozi namenjeni fokusiranju učesnika na unapređivanje agende koja je umesto toga postignuta sporazumima zasnovanim na principima i razumu.
\end{abstract}

Ključne reči: stid, ponos, hrišćansko-jevrejski dijalog, izgradnja mira 